\title{
A BIOMECHANICAL COMPARISON OF MATCHED FOUR-STRAND AND FIVE-STRAND SEMITENDINOSUS- GRACILIS GRAFTS
}

Original Article

ARTIGO ORIGINAL Artículo Original

\author{
ESTUDIO BIOMECÂNICO COMPARATIVO ENTRE INJERTOS DE TENDONES SEMITENDINOSO E GRACILIS \\ CUÁDRUPLEEQUÍNTUPLE
}

\begin{abstract}
ESTUDO BIOMECÂNICO COMPARATIVO ENTRE ENXERTOS QUÁDRUPLOSE QUÍNTUPLOS PAREADOS DE TENDÕES DOS MÚSCULOS SEMITENDÍNEOE GRÁCIL
\end{abstract}

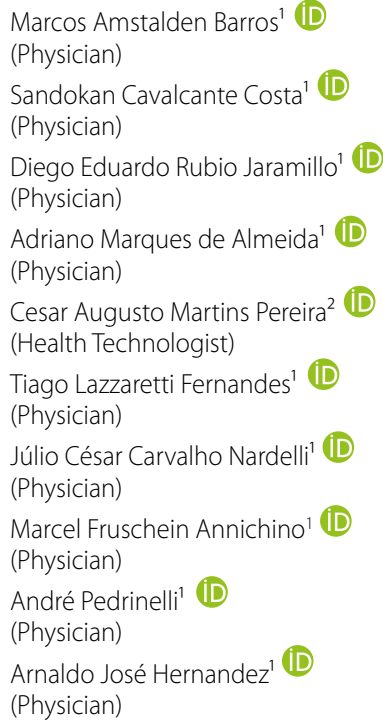

1. Universidade de São Paulo, Faculdade de Medicina, Hospital das Clínicas HCFMUSP, Orthopedics and Traumatology Institute, Sports Medicine Group, São Paulo, SP, Brazil.

2. Universidade de São Paulo Faculdade de Medicina, Hospital das Clínicas HCFMUSP, Orthopedics and Traumatology Institute, Biomechanics Laboratory, São Paulo, SP, Brazil.

\section{Correspondence}

Adriano Marques de Almeida Rua Dr. Ovídio Pires de Campos, 333, LEM, 2nd Floor, Cerqueira Cesar, São Paulo, SP, Brazil. 05403-010 adrianomarquesdealmeida@gmail.com

\begin{abstract}
Introduction: Recent studies have shown that the likelihood of semitendinosus-gracilis graft rupture is inversely correlated to its diameter. A graft can be prepared in a five-strand or four-strand fashion to increase its diameter. However, the biomechanical superiority of five-strand semitendinosus-gracilis grafts is still under debate. Objective: This study aimed to evaluate the biomechanical characteristics of matched four-strand and five-strand human semitendinosus-gracilis grafts. Methods: We evaluated semitendinosus-gracilis tendons harvested from ten fresh human male and female cadavers, aged 18-60 years. Four-strand or five-strand grafts were prepared with the tendons and fixed to wooden tunnels with interference screws. Each graft was submitted to axial traction at $20 \mathrm{~mm} / \mathrm{min}$ until rupture; the tests were donor matched. Data were recorded in real time and included the analysis of the area, diameter, force, maximum deformation and stiffness of the grafts. Results: The diameter, area and tunnel size were significantly greater in the five-strand grafts than in the four-strand grafts. There were no significant differences in biomechanical properties. The area and diameter of the graft were positively correlated to stiffness, and inversely correlated to elasticity. There was no significant correlation between graft size and maximum force at failure, maximum deformation or maximum tension. Conclusion: Five-strand hamstring grafts have greater area, diameter and tunnel size than fourstrand grafts. There were no significant differences in biomechanical properties. In this model using interference screw fixation, the increases in area and diameter were correlated with an increase in stiffness and a decrease in elasticity. Level of evidence $V$; biomechanical study.
\end{abstract}

Keywords: Anterior cruciate ligament reconstruction; Hamstring muscles; Gracilis muscle; Allografts; Cadaver; Transplantation.

\section{RESUMO}

Introdução: Estudos recentes demonstraram que a probabilidade de ruptura do enxerto dos tendões do semitendíneo e do grácil (STG) é correlacionada inversamente com seu diâmetro. Um enxerto pode ser preparado de forma quádrupla ou quíntupla para se aumentar o diâmetro. No entanto, a superioridade biomecânica dos enxertos STG quíntuplos ainda está em debate. Objetivo: Este estudo teve como objetivo avaliar as características biomecânicas dos enxertos STG humanos quádruplos ou quíntuplos pareados. Métodos: Foram avaliados tendões STG retirados de dez cadáveres masculinose femininos frescos, com idades entre 18 e 60 anos. Os enxertos quádruplos ou quíntuplos foram preparados com os tendões e fixados em túneis de madeira com parafusos de interferência. Cada enxerto foi submetido à tração axial a $20 \mathrm{~mm} / \mathrm{min}$. até a ruptura; os testes foram pareados de acordo com os doadores. Os dados foram registrados em tempo real e incluíram a análise de área, diâmetro, força, deformação máxima erigidez dos enxertos. Resultados: O diâmetro, a área e o tamanho do túnel foram significativamente maiores nos enxertos quíntuplos do que nos enxertos quádruplos. Não houve diferenças significativas nas propriedades biomecânicas. A área e o diâmetro do enxerto foram correlacionados positivamente com a rigidez e inversamente com a elasticidade. Não houve correlação significativa entre o tamanho do enxerto e a força máxima na falha, deformação máxima ou tensão máxima. Conclusão: Os enxertos quíntuplos dos músculos isquiotibiais têm maior área, diâmetro e tamanho do túnel do que os enxertos quádruplos. Não houve diferenças significativas nas propriedades biomecânicas. Neste modelo de fixação com parafuso de interferência, aumentos da área e do diâmetro foram correlacionados com o aumento da rigidez e a diminuição na elasticidade. Nível de evidência V; Estudo Biomecânico.

Descritores: Reconstrução do ligamento cruzado anterior; Músculos isquiossurais; Músculo grácil; Aloenxertos; Cadáver; Transplante.

\section{RESUMEN}

Introducción: Estudios recientes demostraron que la probabilidad de ruptura de los injertos semitendinoso y gracilis (STG) durante el pos operatorio de reconstrucción de ligamento cruzado anterior (LCA) está inversamente 
correlacionada a su diámetro. Un injerto puede ser preparado para obtener cuatro o cinco hebras para aumentar su diámetro, pero la superioridad biomecanica de los injertos STG de cinco hebras aún se mantiene en discusión. Objetivo: Evaluar las características biomecánicas de los injertos STG de humanos de cuatro o cinco hebras por pares. Métodos: Fueron evaluados tendones STG de diez cadaveres masculinos y diez cadaveres femeninos frescos, entre los 18 y 60 años. Los injertos de cuatro y cinco hebras fueron fijados en túneles de madera con tornillos de interferencia. Cada injerto fue sometido a una tracción axial de $200 \mathrm{~mm} / \mathrm{min}$ hasta su ruptura; estos tendones fueron separados por pares de acuerdo con sus donadores. Los datos fueron registrados en tiempo real y incluyeron el análisis del área del injerto, diámetro, fuerza, deformación máxima y rigidez. Resultados: Los resultados sobre el diámetro, el área y el tamaño del túnel fueron significativamente mayores en los injertos de cinco hebras que en los de cuatro. No existieron diferencias significativas en las propiedades biomecánicas. El área y el diámetro del injerto fueron correlacionados positivamente con la rigidez e inversamente con la elasticidad. No existió correlación significativa entre el tamaño del injerto y la fuerza máxima al momento de la falla, Máxima deformación o máxima tensión. Conclusión: Los injertos de isquiotibiales de cinco hebras tienen una área, diámetro y tamaño de túnel más grande que los injertos de cuatro hebras. No hubieron diferencias biomecánicas significativas. Los aumentos de área y diámetro en este modelo con la fijación de tornillo de interferencia fueron correlacionados con aumento de en la rigidez y una disminución en la elasticidad. Nivel de evidencia V; estudio biomecánico.

Descriptores: Reconstrucción del ligamento cruzado anterior; Músculos isquiosurales; Músculo grácil; Aloinjertos; Cadáver; Trasplante.

\section{INTRODUCTION}

Anterior cruciate ligament $(A C L)$ reconstruction using semitendinosus gracilis (STG) grafts is increasing; recent studies have shown that the use of the STG graft is replacing the patellar tendon graft in increasing numbers. ${ }^{1}$ Hamstring grafts are associated with less anterior knee pain and fewer extensor mechanism complications than bone-patellar tendon-bone (BPTB) autografts, while presenting a higher load to failure. ${ }^{2,3}$ Similar clinical outcomes areobserved with both techniques. ${ }^{4}$ One of the main concerns when using STG grafts is the inherent heterogeneity in the graft diameter, which can cause important variability in the biomechanical properties of the graft, leading to increased failure risk. ${ }^{7}$ Recent papers have shown that ACL reconstruction using larger STG graft diameters has a lower risk of revision surgery. Grafts of $7 \mathrm{~mm}$ or less had a revision rate of $13.6 \%$, compared to $1.7 \%$ for grafts greater than $8 \mathrm{~mm} .{ }^{8}$ Additionally, the likelihood of a revision surgery was 0.86 times lower with every increment of $0.5 \mathrm{~mm}$ in the STG graft diameter. ${ }^{9}$ One possible solution when the surgeon faces a thin STG graft is to use a three-folded semitendinosus and a two-folded gracilis graft, therefore making a five-strand STG graft instead of the usual four-strand graft. The results of this strategy have shown a graft that has a larger diameter and is possibly stronger. ${ }^{10}$

However, a recent biomechanical study using a fixed-loop device (Endobutton) compared four-strand and five-strand STG grafts and showed an increased graft diameter but no significant difference in stiffness or displacement. The authors suggest that the attachment of the additional graft with sutures did not contribute to improved biomechanical properties of the graft at time zero. ${ }^{11}$ The latest systematic review comparing four-strand and 5 -strand grafts, analysing clinical and biomechanical studies, found no difference in outcomes after $\mathrm{ACL}$ reconstruction with either graft constructo. ${ }^{12}$

Therefore, we performed a biomechanical study comparing matched four- strand and five-strand STG grafts that were fixated with interference screws at both ends vs. the fixed-loop cortical fixation devices. Our purpose was to verify whether there is a difference in biomechanical properties between the four-strand or five-strand grafts in this type of construct at time zero.

\section{MATERIALS AND METHODS}

Semitendinosus and gracilis tendons were harvested from fresh human male and female cadavers, aged 18 to 60 years. The cadavers were obtained from the Obituary of our Service. Specimens presenting signs of previous pathological conditions such as deformities, surgical scars or clinical evidence of lesions were not included in this study.

Anatomic dissection was conducted bilaterally through a posterior approach to the knees to harvest the semitendinosus and gracilis tendons for use as grafts. The wound was closed in a layered fashion. Harvested grafts were identified in relation to the knee side of the cadaver and cleaned from the adjacent muscle. They were packed in a saline solution and frozen for posterior testing.

At the time of the testing, the grafts were defrosted and prepared as a quadruple- or quintuple-strand graft at the Biomechanical Laboratory of our Institute. The testing of the grafts occurred in a paired manner, in which a four-strand graft would be compared with a five- strand graft from the contralateral knee of the same body. After testing, grafts were returned to the Obituary Service for proper disposal.

The four-strand grafts were prepared with semitendinosus and gracilis tendons that were folded in half. The free ends of the grafts were whip stitched with $1.0 \mathrm{Vicryl}^{\bullet}$ sutures. (Figure 1) The five-strand grafts were prepared by combining a triple semitendinosus graft and a double gracilis graft with a modification of the technique described by Kyle. ${ }^{13}$ The gracilis grafts were folded in half, and the free ends were whip stitched. The semitendinosus grafts were folded in threes, and the free limb end and the folded limb end were whip stitched. Again, all closures were performed using 1.0 Vicryl sutures. (Figure 1) We measured the length, central area, and central diameter of the grafts. The area was measured using a measurement device made by a height gauge (Mitutoyo dial indicator, $0.01-\mathrm{mm}$ resolution), a channel with dimensions of $9.6 \mathrm{~mm}$ (width) $\times 15 \mathrm{~mm}$ (depth) and a parallelepiped-shaped actuator, which slid through the channel and was attached to the stem of the dial indicator. First, the height gauge was set to zero with the actuator in contact with the base of the channel. The grafts were then introduced between

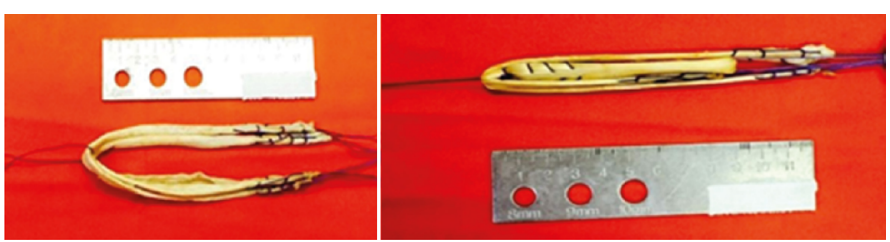

Figure 1. Four-strand and five-strand grafts. 
the actuator and the channel and placed under $12 \mathrm{~N} . \mathrm{m}-2$ pressure to obtain a rectangular shape. The area was calculated as the product of the graft height (measured by the height gauge) and channel width. The area's corresponding diameter was calculated using the formula $D=\sqrt{ } A .4 / \pi$, in which $D$ is the graft's diameter, $A$ is the graft's area and $\pi=3,14159265$. Mechanical testing: The tests were performed in a universal mechanical testing machine Kratos ${ }^{\circledR} \mathrm{K} 5002$ (Kratos Equipamentos Industriais), equipped with an electronic load cell of $981 \mathrm{~N}$. The system precision for the load measure was 0,981 N. The equipment was linked to a computer, and the data were acquired and processed with a data acquisition system ADS2000 (Lynx Tecnologia Ltda). ${ }^{14}$ Each graft was connected to the testing machine through two tubes constructed of the Brazilian wood Simaroubaamara. The tubes were attached to the base and the load cell of the machine through two 4-mm diameter metallic pins. The tubes were $80 \mathrm{~mm}$ in length and 27,5 $\mathrm{mm}$ in diameter, with a 6-mm diameter passing hole. According to the diameter of the graft in its proximal and distal regions, a 30-mm deep hole with an extra 1-mm diameter was made in one of the tube's extremities for graft fixation with a metallic interference screw that had the same diameter as the graft.

To contain any expansion of the external part of the wooden tubes in the area of the graft's fixation, two high-impact polystyrene (HIPS) belts were constructed with a 3D printer. Each belt was attached to the tube (Figure 2) and fixated by the turning of a screw at $1 \mathrm{~N}$.m torque with the use of a 12 N.m torque meter, model DV-14 (Lorenz Messtechnik $\mathrm{GmbH}$, Germany).

The grafts were fixated with blunt, metallic interference screws using a $12 \mathrm{~N}$.m torque meter attached to a screwdriver. The strength of the screw insertion was registered in the computer with the same data acquisition system mentioned previously. A 30-mm distance was established from the central part of the graft, which was defined by the distance between the two tubes. However, because of graft length variations, the final distance was measured using a 0.05-resolution Mitutoyo caliper with the tubes fixated to the testing machine and submitted to a $3 \mathrm{~N}$ pre-charge. Each graft was submitted to axial tension at a speed of $20 \mathrm{~mm} / \mathrm{min}$ until its rupture. Force and deformation were registered in real time. Maximal force, maximal deformation (peak of the force vs. deformation graph), stiffness, and elasticity were evaluated. Stiffness was calculated as force divided by deformation measured between two points in the linear region of the graph.

\section{Ethics}

This study was approved by the Ethics Committee and all grafts were harvested and tested after an informed consent was signed by the cadavers' relatives.

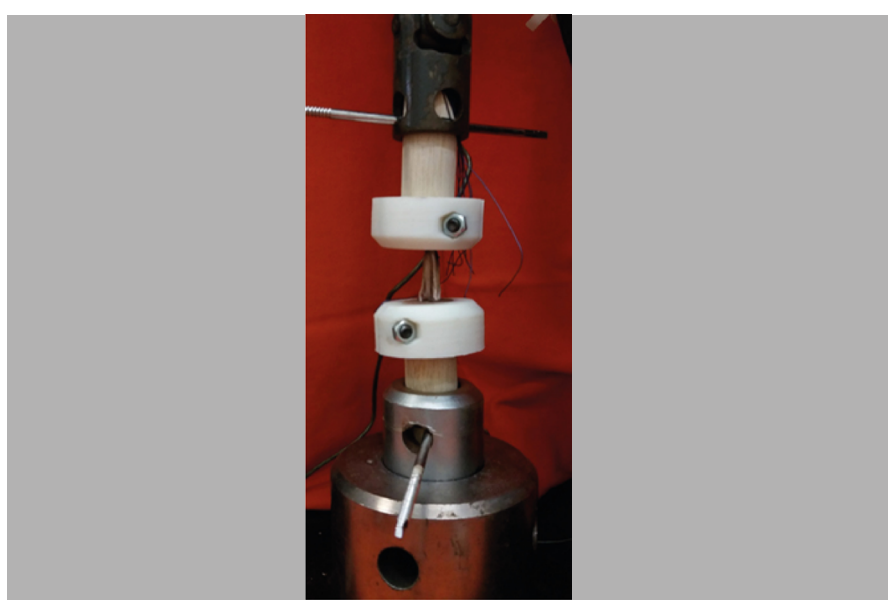

Figure 2. A graft fixed to the testing machine showing the wooden tubes and containing belts.

\section{RESULTS}

Graft diameter, area and tunnel size were significantly higher in the five-strand construct compared with the four-strand construct. The graft length was significantly shorter in the five-strand graft, as expected. (Table 1) No significant differences in biomechanical properties were observed comparing the matched five-strand and four-strand constructs. We observed a significant correlation between the graft size and biomechanical properties. The graft area and diameter were positively correlated to stiffness (Pearson's coefficient 0.48, $p=.03$ ) and inversely correlated to elasticity (Pearson's coefficient $-0.47, p=.035$ ). No significant correlations were found between the graft size and maximal force to failure and maximal deformation or maximal tension.

Table 1. Four-strand and five-strand STG graft characteristics and biomechanical properties.

\begin{tabular}{c|c|c|c}
\hline & Four-strand & Five-strand & P-value \\
\hline Length $(\mathrm{mm})$ & $112.9 \pm 16.1$ & $84.3 \pm 5.5$ & $<.001$ \\
\hline Area $\left(\mathrm{mm}^{2}\right)$ & $58.6 \pm 12.9$ & $70.2 \pm 15.2$ & .045 \\
\hline Diameter $(\mathrm{mm})$ & $8.6 \pm 0.9$ & $9.4 \pm 1$ & .039 \\
\hline Tunnel size $(\mathrm{mm})$ & $8.5 \pm 0.5$ & $9.9 \pm 0.9$ & $<.001$ \\
\hline Stiffness $(\mathrm{N} / \mathrm{mm})$ & $44 \pm 11.4$ & $50.5 \pm 12.74$ & .25 \\
\hline Elasticity $(\mathrm{MPa})$ & $20.2 \pm 4.9$ & $18 \pm 5.8$ & .36 \\
\hline $\mathrm{F}_{\max }(\mathrm{N})$ & $427.5 \pm 149.4$ & $469.5 \pm 27.2$ & .22 \\
\hline $\mathrm{D}_{\max }(\mathrm{mm})$ & $17.4 \pm 4.9$ & $15.5 \pm 6.7$ & .39 \\
\hline $\mathrm{D}_{\max }(\%)$ & $67,8 \pm 22,8$ & $65,7 \pm 32$ & .87 \\
\hline $\mathrm{T}_{\max }(\mathrm{MPa})$ & $7.33 \pm 2.6$ & $6.9 \pm 2.2$ & .35 \\
\hline
\end{tabular}

\section{DISCUSSION}

Five-strand STG grafts prepared with triple semitendinosus and double gracilis strands had greater diameter, area and tunnel size than four-strand grafts prepared with semitendinosus and gracilis tendons folded in half, as expected; however, we did not find a significant difference in the biomechanical properties between the four-strand and five-strand constructs.

There is evidence in the literature that a greater hamstring graft diameter corresponds to a greater graft strength, showing a correlation between graft size and ultimate failure load. ${ }^{2}$ Magnussen et al. ${ }^{8}$ prospective study with 256 patients and a mean follow-up of 14 months showed that a decreased hamstring autograft size is a predictor of early graft revision. Snaebjörnsson et al. ${ }^{9}$ provided further evidence of the importance of the hamstring autograft diameter. His cohort study with 2240 patients from the Swedish National Knee Ligament Register (SNKLR) undergoing primary $A C L$ reconstruction with hamstring autograft showed that an increase in the graft diameter between 7.0 and $10.0 \mathrm{~mm}$ resulted in a 0.86 times lower likelihood of revision surgery with every $0.5 \mathrm{~mm}$ increase.

However, when we artificially increased graft diameter with five-strand instead of four-strand STG grafts, biomechanical studies failed to demonstrate superior biomechanical properties of the former constructs at time zero. Vaillant et al., ${ }^{11}$ using a loop construct for fixation of the graft, observed that the free strand of the semitendinosus was not effective in improving the biomechanical properties of the graft. ${ }^{11}$ In our study, we aimed to reproduce the interference screw fixation to achieve a better incorporation of the additional semitendinosus strand in the construct. Comparing the matched pairs of both types of constructs, we did not find a significant difference in the biomechanical properties, although we observed a significant positive correlation between the graft diameter and stiffness.

As expected, the five-strand grafts were shorter than the four-strand grafts $(84.3 \pm 5.5 \mathrm{~mm}$ vs. $112.9 \pm 16.1 \mathrm{~mm}, \mathrm{P}<.001)$. This graft length should be sufficient for $A C L$ reconstruction, but surgeons must be aware of the graft's final length and the technique that will be applied. 
One limitation of our study was the graft fixation on wood models. We opted for wood models to standardize our constructs. Cadaveric human bones have different biomechanical properties such as density and resistance, which could interfere with the results. This construct probably had effects on the biomechanical testing, particularly on maximum resistance, once most of the ruptures occurred at the fixation zone. Maximum force (Fmax) was probably mostly influenced by the fixation interface than by the graft characteristics. In contrast, elasticity and stiffness are determined by the graft properties, not by the fixation method.

\section{CONCLUSIONS}

In our study, the five-strand hamstring grafts had significantly larger area, diameter and tunnel size than the four-strand hamstring grafts. However, there were no significant differences in stiffness and elasticity when comparing the matched pairs of constructs, although we observed a significant correlation between graft area and stiffness and elasticity.

All authors declare no potential conflict of interest related to this article

AUTHORS' CONTRIBUTIONS: Each author made significant individual contributions to this manuscript. MAB:Writing, data analysis, revision of the manuscript; SCC: Performed the literature review, preparation of the whole research project, revision and performed the procedures; DERJ: Performed the literature review, preparation of the whole research project, revision and performed the procedures; AMA:Writing, intellectual concept, preparation of the whole research project, data analysis, statistical analysis, revision of the manuscript; MFA: Literature review, manuscript review; CAMP: Preparation of the whole research project, data analysis; TLF, JCCN, AP, and AJH: Contributed to the intellectual concept of the study.

\section{REFERENCES}

1. Kvist J, Kartus J, Karlsson J, Forssblad M. Results from the Swedish national anterior cruciate ligament register. Arthroscopy. 2014;30(7):803-10.

2. Hamner DL, Brown CH Jr, Steiner ME, Hecker AT, Hayes WC. Hamstring tendon grafts for reconstruction of the anterior cruciate ligament: biomechanical evaluation of the use of multiple strands and tensioning techniques. J Bone Joint Surg Am. 1999;81(4):549-57.

3. Wilson TW, Zafuta MP, Zobitz M. A biomechanical analysis of matched bone- patellar tendon-bone and double-looped semitendinosus and gracilis tendon grafts. Am J Sports Med. 1999;27(2):202-7.

4. Sajovic M, Strahovnik A, Dernovsek MZ, Skaza K. Quality of life and clinical outcome comparison of semitendinosus and gracilis tendon versus patellar tendon autografts for anterior cruciate ligament reconstruction: an 11-year follow-up of a randomized controlled trial. Am J Sports Med. 2011;39(10):2161-9.

5. Tuman JM, Diduch DR, Rubino LJ, Baumfeld JA, Nguyen HS, Hart JM. Predictors for hamstring graft diameter in anterior cruciate ligament reconstruction. Am J Sports Med. 2007;35(11):1945-9

6. Bickel BA, Fowler TT, Mowbray JG, Adler B, Klingele K, Phillips G. Preoperative magnetic resonance imaging crosssectional area for the measurement of hamstring autograft diameter for reconstruction of the adolescent anterior cruciate ligament. Arthroscopy. 2008;24(12):1336-41.

7. Conte EJ, Hyatt AE, Gatt CJJ, Dhawan A. Hamstring autograft size can be predicted and is a potential risk factor for anterior cruciate ligament reconstruction failure. Arthroscopy. 2014;30(7):882-90

8. Magnussen RA, Lawrence JTR, West RL, Toth AP, Taylor DC, Garrett WE. Graft size and patient age are predictors of early revision after anterior cruciate ligament reconstruction with hamstring autograft. Arthroscopy. 2012;28(4):526-31.

9. Snaebjörnsson T, Hamrin Senorski E, Ayeni OR, Alentorn-Geli E, Krupic F, Norberg F, et al. Graf diameter as a predictor for revision anterior cruciate ligament reconstruction and KOOS and EQ-5D values: a cohort study from the swedish national knee ligament register based on 2240 patients. Am J Sports Med. 2017;45(9):2092-7.

10. Lavery KP, Rasmussen JF, Dhawan A. Five-strand hamstring autograft for anterior cruciate ligament reconstruction. Arthrosc Tech. 2014;3(4):e423-6.

11. Vaillant ER, Parks BG, Camire LM, Hinton RY. Five-strand versus four- strand hamstring tendon graft technique for anterior cruciate ligament reconstruction: a biomechanical comparison. J Knee Surg. 2017;30(9):916-9.

12. Smith JH, Houck DA, Hart JA, Vidal AF, Frank RM, Bravman JT, et al. Five-strand hamstring autografts for anterior cruciate ligament reconstruction: a systematic review. Orthop J Sports Med. 2019;7(2):2325967119826094.

13. Lavery KP, Rasmussen JF, Dhawan A. Five-strand hamstring autograft for anterior cruciate ligament reconstruction. Arthrosc Tech. 2014;3(4):e423-6.

14. Górios C, Hernandez AJ, Amatuzzi MM, Leivas TP, Pereira CAM, Bölliger Neto R, et al. Rigidity of the knee anterior cruciate ligament and grafts to reconstruct it with the patellar ligament and with the semitendinosus and gracilis muscles. Acta Ortop Bras. 2001;9(2):26-40. 